\title{
Implementation of monitoring for genetically modified rapeseed in Serbia
}

\author{
Zorica Nikolić $^{1} \bowtie \cdot$ Milka Vujaković $^{1} \cdot$ Ana Marjanović Jeromelaç ${ }^{1} \cdot$ Dušica Jovičić $^{1}$ \\ 1 Institute of Field and Vegetable Crops, Maksima Gorkog 30, Novi Sad, Serbia \\ $\triangle$ Corresponding author: nikolicz@ifvcns.ns.ac.rs \\ Received December 17, 2009 / Accepted May 31, 2010 \\ Published online: September 15, 2010 \\ (c) 2010 by Pontificia Universidad Católica de Valparaíso, Chile
}

\begin{abstract}
Genetically modified (GMO) rapeseed (Brassica napus) is not grown commercially in European Union, but several lines have been approved for production and use as food and feed. A case-specific monitoring of herbicide-tolerant rapeseed, events RT73, RF3 and T45 was established by Ministry of Agriculture of Republic of Serbia. The objectives of the present study were to introduce methods for detection of herbicide-tolerant GM oilseed rape, investigate occurrence and monitor the presence of GM rapeseed in seed and the feed products, as well as to develop a protocol for quantification. The study was based on 48 samples, rapeseed (33) and feed (15) products, imported from EU countries (Germany, Belgium, France, Czech Republic, Austria) and from domestic market. Seven positive feed samples and no positive seed samples have found. The percent of GMO in feed samples, estimated on semiquantitative way, was below labelling threshold. Adventitious presence of GM materials in non-GM grain, derived food and feedstuffs is a concern to international grain trade and needs continuous monitoring.
\end{abstract}

Keywords: genetically modified organism, monitoring, rapeseed

\section{INTRODUCTION}

As the agricultural biotechnology continues to develop, the number of genetically modified (GM) crops that have been approved for commercialization globally has increased. In 2008, 25 countries planted GM crops and 55 have granted regulatory approvals for import, food and feed use and for release into the environment (James, 2008). In the period 2001-2007 area plantings of genetically modified rapeseed (Brassica napus) have more than doubled to 5.5 million hectares.

While in the European Union no commercial cultivation of GM rapeseed takes place, in the USA and in particular in Canada over $80 \%$ of the area cultivated with rapeseed was planted with GM varieties. All of the GM rapeseed grown throughout the world were herbicide resistant, which enables a more efficient and effective approach to 
weed control. Several lines of GM rapeseed, RT73, MS8/RF3 and T45, have been approved for use as food and feed in EU.

With the introduction of GM crops into the world's food/feed supply, the risk of GM food/feed has been a concern by consumers, and more than 40 countries and regions have issued specific GM labelling regulations, including a labelling threshold such as $0.9 \%$ in the European Union, $3 \%$ in Korea, and $5 \%$ in Japan (Brod and Arisi, 2008).

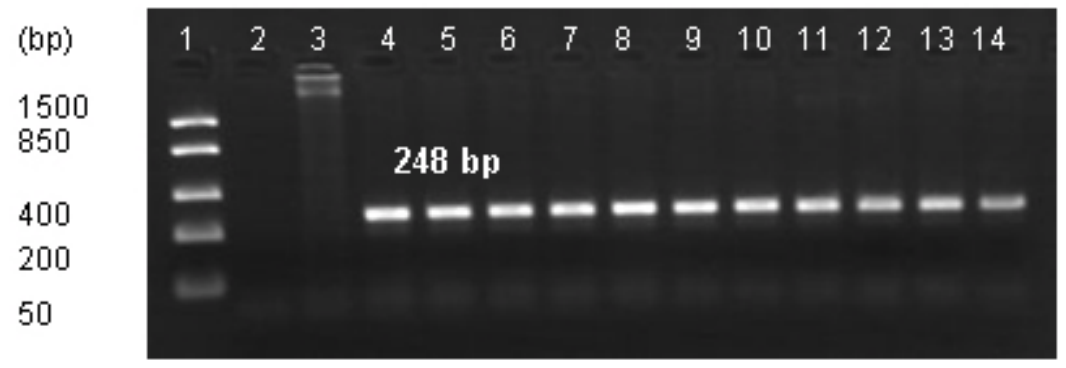

Fig. 1 Agarose gel analysis of PCR products of reaction performed with the primers for rapeseed specific internal target phosphoenolpiruvate carboxylase gene. The amplificability of the DNA extracted by CTAB method was confirmed through visualization of amplicons 248 bp. In line 1 molecular weight marker; line 2 blank; line 3 soybean (negative control); line 4 rapeseed (positive control); lines 5-14 rapeseed samples.

Traceability of GM plants has important part in quality control and monitoring of primary and processed plant products. For rapeseed, as for other crops, adventitious and technically unavoidable GMO contamination of the harvested product below the $0.9 \%$ threshold is permitted without labelling in the EU.

A concept for a case-specific monitoring of herbicide-tolerant GM oilseed rape, events RT73, RF3 and T45, has been developed by Ministry of Agriculture of Republic of Serbia. The objectives of the present study were to introduce methods for detection of herbicide-tolerant GM oilseed rape, investigate occurrence and monitor the presence of GM rapeseed in seed and feed products, as well as to develop a semi-quantitative protocol for the quantification.

\section{MATERIALS AND METHODS}

The study was based on 48 samples, rapeseed (Brassica napus) (33) and feed rapeseed derived products (15) imported from EU countries (Germany, Belgium, France, Czech Republic and Austria) and as well as from domestic market.

The Certified Reference Material were used canola leaf DNA T45 (AOCS 0208-A) and Rf3 (AOCS 0306-G) and canola seed RT73 (AOCS.0304).

Primers used in this work were listed in Table 1. 


\section{DNA extraction}

A CTAB method (Lipp et al. 1999) was followed for the extraction and purification of DNA from all samples. Physical quality of the extracted DNA was checked by electrophoresis in a 1\% (w/v) agarose gel, and purity was confirmed by OD 260/280 $\mathrm{nm}$ comparison.

\section{PCR}

In order to establish a calibration curve for comparison of the unknown samples, DNA was prepared mixing different proportion GM and non-GMO DNA. The linear range obtained was $0.05 \%$ to $1 \%$ GMO as was described by Cazzola and Petruccelli (2006). Reaction condition for RT73, RF3 and T45 were adjusted to quantify with a treshold level of $0.05 \%(\mathrm{w} / \mathrm{w})$.

The PCR was carried out using premix of 2x PCR Master Mix, (Fermentas, Lithuania) containing $4 \mathrm{mM} \mathrm{MgCl}, 0.4 \mathrm{mM}$ dNTP, 0.05 units/ $\mu \mathrm{l}$ Taq DNA Polymerase (recombinant).

PCR was performed in a final volume of $25 \mu \mathrm{l}$ of PCR mix containing $0.3 \mathrm{pmol} / \mu \mathrm{l}$ primers for RT73 and FMV or 0.6 pmol/ $\mu$ l primers for $35 \mathrm{~S}, \mathrm{NOS}, \mathrm{T} 45$ and RF3 and approx. $100 \mathrm{ng}$ DNA was used.

Amplifications were carried out in a Mastercycler ep gradient $\mathrm{S}$ termocycler (Eppendorf, Germany) under the following program: $95^{\circ} \mathrm{C}$ for $3 \mathrm{~min}$ followed by 35 cycles of $95^{\circ} \mathrm{C}$ for $25 \mathrm{sec}, 56^{\circ} \mathrm{C}$ for $30 \mathrm{sec}$ (Tnos, T45, RT73, FMV) or $60^{\circ} \mathrm{C}$ (P35S, RF3), $72^{\circ} \mathrm{C}$ for $40 \mathrm{sec}$, and at $72^{\circ} \mathrm{C}$ for $5 \mathrm{~min}$.

Table 1. Primers used for the detection of genetically modified rapeseed.

\begin{tabular}{|c|c|c|c|}
\hline Primer & Sequence $5^{\prime}$ to $3^{\prime}$ & $\begin{array}{l}\text { Product } \\
\text { (bp) }\end{array}$ & Reference \\
\hline PEPC & $\begin{array}{l}\text { GCTAGTGTAGACCAGTTCTTG } \\
\text { CACTCTTGTCTCTTGTCCTC }\end{array}$ & 248 & $\begin{array}{c}\text { Hellebrand et al. } \\
1998\end{array}$ \\
\hline P35S & $\begin{array}{l}\text { GCTCCTACAAATGCCATCA } \\
\text { GATAGTGGGATTGTGCGTCA }\end{array}$ & 195 & Lipp et al. 1999 \\
\hline Nos & $\begin{array}{l}\text { GCATGACGTTATTTATGAGATGGG } \\
\text { GACACCGCGCGCGATAATTTATCC }\end{array}$ & 118 & Lipp et al. 2001 \\
\hline FMV & $\begin{array}{l}\text { AGTCCAAAGCCTCAACAAGGTC } \\
\text { CATTAGTGAGTGGGCTGTCAGG }\end{array}$ & 418 & Jaccaud et al. 2003 \\
\hline RT 73 & $\begin{array}{l}\text { CCA TAT TGA CCA TCA TAC TCA TTG CT } \\
\text { GCT TAT ACG AAG GCA AGA AAA GGA }\end{array}$ & 108 & $\begin{array}{l}\text { Monsanto } \\
\text { Biotechnology } \\
\text { Regulatory } \\
\text { Sciences, } 2004\end{array}$ \\
\hline T45 & $\begin{array}{l}\text { TCCCATTTATTTACGGTCAC } \\
\text { CCATGGGAATTCATTTACAA }\end{array}$ & 233 & Yang et al. 2006 \\
\hline RF3 & $\begin{array}{l}\text { GGAATTAACATCTACAAATTGCCTTT } \\
\text { TTGTAATTAGAAACCCTGAAATTTGT }\end{array}$ & - & GMDD \\
\hline
\end{tabular}


The PCR amplification products were separated by electrophoresis in $2 \%(\mathrm{w} / \mathrm{v})$ agarose gel containing ethidium bromide (0.5 gml-1) using 1XTBE buffer. Images were recorded with DOC PRINT documentation system (Vilber Lourman, USA).

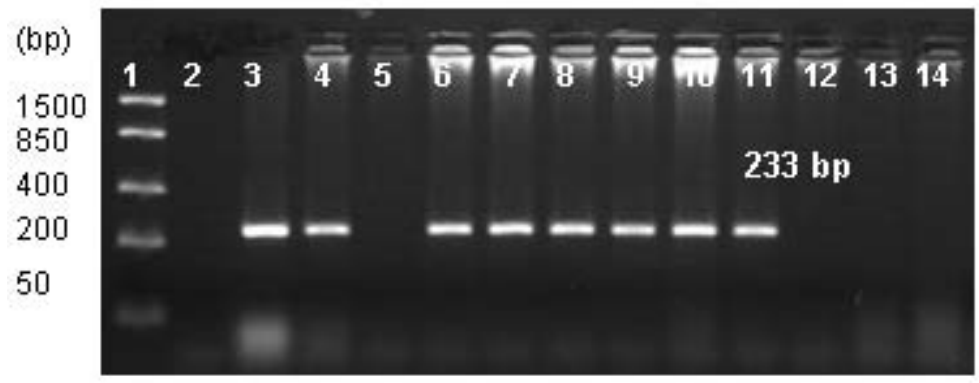

Fig. 2 Event specific PCR detection of rapeseed event T45 in feed samples tested positive for presence of the 35S promoter, T nos or FMV. In line 1 molecular weight marker; line 2 blank; lines 3 and 4 transgenic event T45 (positive controls); line 5 non-GMO rapeseed (negative control); 6-14 feed samples.

\section{RESULTS AND DISCUSSION}

The results presented in this study confirmed that the CTAB protocol can be used for DNA extraction and purification from rapeseed and feed products. The amplificability of the DNA extracted from the samples was confirmed using primers for host specific internal target phosphoenolpiruvate carboxylase gene, through visualization of amplicons $248 \mathrm{bp}$ (Figure 1). In order to monitor potential inhibition arising from an individual sample, in routine application, an inhibition control in the method is a requisite (Forte et al. 2005).

Genetic control elements such as the Cauliflower Mosaic Virus 35S promoter (CaMV P35S) and the Agrobacterium tumefaciens nos terminator are present in around 95\% of currently commercialized GMO plants. Moreover, the $35 \mathrm{~S}$ promoter and nos terminator are DNA fragments of naturally occurring plant pathogens what could lead to a positive result, so the samples should be analyzed for naturally occurring infections (Chaouachi et al. 2008).

In the present work, PCR assay has been used to distinguish the genetically modified samples from the non-genetically modified ones by screening for the presence of three genetic elements: P35S, T nos and FMV. We have found seven positive feed samples and no positive seed samples. The screening method is associated with a particular risk of yielding false positives. Gene and construct-specific methods are more specific but cannot distinguish between different GMOs if the same construct has been integrated (Holst-Jensen et al. 2003). To overcome these problems, the event-specific PCR must be performed. All GM-positive samples were analyzed using the event specific primers for T45, RF3 and RT73 (Table 1). 
As expected, in the established PCR assay, the primers specific for T45 oilseed rape (Yang et al. 2006) produced 233 bp DNA fragment in T45 positive controls (Figure 2, lines 3 and 4) and no amplification in non-transgenic rapeseed (Figure 2, line 5). All samples were analysed in triplicate. Two samples positive for P35S promotor were positive for event T45 (Figure 2, lines 6-11). Two out of five RF3 positive samples contained both RF3 and RT 73 events.

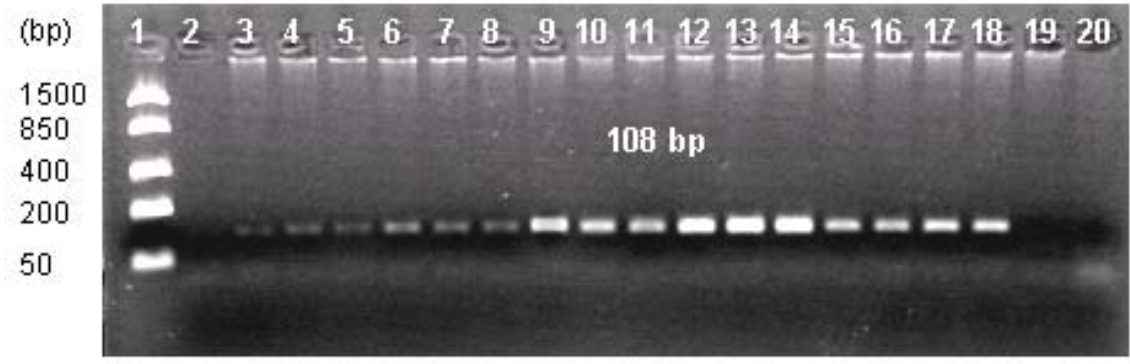

Fig. 3 Semi-quantitative analysis of RT73 rapeseed content in feed samples. In line 1 molecular weight marker; line 2 blank, lines 3-14 represent the calibration curve in range 0.05 to $1 \%$ of RT73 content (3-5 0.05\%, 6-8. 0.1\%, 9-11 0.5\%, 12-14 1\%); lines 15-18 RT 73 positive feed samples, lines 19-20 negative controls.

It this work was shown that the content of GM rapeseed could be estimated on the semi-quantitative method. By visual comparison between the DNA obtained from samples and the DNA observed in the calibration curve samples, it is possible to estimate the range of GMO content. The intensity of the specific band of $108 \mathrm{bp}$ reflect the actual GMO content of RT73 rapeseed, with increasing intesity from $0.05 \%$ to $1 \%$ GMO content (Figure 3, lines 3-14). The percent of GMO in positive feed samples was less than $1 \%$, in the range from $0.1 \%$ to $1 \%$ (Figure 3 , lines $15-18$ ). It was below the threshold level, which is an expected result since all samples originated from EU where control and labelling of products is mandatory.

The similar results, based on 35S promoter, were reported by Tozzini et al. (2000) for soybean and maize seed samples. It was demonstrated by Cazzola and Petruccelli (2006) that semi-quantitative analysis could be applied on the simple food samples contained maize and soybean.

Studer et al. (1998) reported that under certain circumstances, could be considered and used semi-quantitative method, but not routinely in GMO detection. In contrast, Tozzini et al. (2000) had shown that the semi-quantitative protocol could be successfully applied in routinely assess the quantity of transgenic grains present in commercial shipments of corn and soybean.

Although the cultivation of GM plants has not yet been approved in Serbia, their import is expected to increase, and their unforeseen, intended or accidental cultivation may eventually occur as has been revealed for Roundup Ready soybean (Nikolić et al. 2009). 
There were several reports which have emphasized the importance of surveillance wherever GM plants are grown or transported, including not only in cultivated fields but also in unexpected places, e.g., wastelands, harbour surroundings, and roadsides. The presence of GM rapeseed and maize along transportation routes and around grain ports have been reported in Japan, Canada and Korea (Park et al. 2010).

Contaminations in pedigreed canola seedlots with herbicide resistance traits has been referred by Friesen et al. (2003). Appropriate monitoring is necessary to detect the possible dispersal of imported GM plant seeds in the transportation system, as well as through the transfer of transgenes to wild relatives via pollen flow.

Adventitious presence of GM materials in non-GM grain, derived food and feedstuffs is a concern to international grain trade and needs continuous monitoring by traditional and innovative techniques of investigation (Demeke et al. 2006). The development of a practical detection method is required to confirm the validity of labelling system and to monitor the status of circulation for GMO.

\section{CONCLUDING REMARKS}

The CTAB protocol was suitable for the extraction of amplifiable DNA from rapeseed and feed samples. Well established semi-quantitative PCR protocol, used in this work, is also suitable for the estimation of content of GM in this kind of samples. Our results confirm the presence of low content of GM in feed products. This paper reports data concerning the detection of GM rapeseed stipulated directions for using and labelling food and feed containing GMO in Serbia. We hope that some of the methods described are useful to laboratories intending to conduct GM detection.

Financial support: This work was part of a project no. 20081 supported by Ministry of Science and Technological Development, Serbia

\section{REFERENCES}

BROD, Fábio Cristiano Angonesi and ARISI, Maisonnave Anna Carolina. Quantification of Roundup Ready ${ }^{\mathrm{TM}}$ soybean in Brazilian soy-derived foods by real-time PCR. International Journal of Food Science \& Technology, June 2008, vol. 43, no. 6, p. 1027-1023. [CrossRef]

CAZZOLA, María Laura and PETRUCCELLI, Silvana. Semiquantitative analysis of geneticaly modified maize and soybean in food. Electronic Journal of Biotechnology, June 2006, vol. 9, no. 3. [CrossRef]

CHAOUACHI, Maher; FORTABAT, Marie Noelle; GELDREICH, Angèle; YOT, Pierre; KERLAN, Camille; KEBDANI, Naïma; AUDEON, Colette; ROMANIUK, Marcel and BERTHEAU, Yves. An accurate real-time PCR test for the detection and quantification of cauliflower Mosaïc virus (CaMV): applicable in GMO screening. European Food Research and Technology, July 2008, vol. 227, no. 3, p. 789-798. [CrossRef]

DEMEKE, T.; PERRY, D.J. and SCOWCROFT, W.R. Adventitious presence of GMOs: scientific overview for Canadian grains. Canadian Journal of Plant Science, January 2006, vol. 86, no. 1, p. 1-23.

FRIESEN, Lyle F.; NELSON, Alison G. and VAN ACKER, Rene C. Evidence of contamination of pedigreed canola (Brassica napus) seed lots in western Canada with genetically 
engineered herbicide resistance traits. Agronomy Journal, September 2003, vol. 95, no. 5, p. 1342-1347.

FORTE, V.T.; DI PINTO, A.; MARTINO, C.; TANTILLO, G.M.; GRASSO, G. and SCHENA, F.P. A general multiplex-PCR assay for the general detection of genetically modified soya and maize. Food Control, July 2005, vol. 16, no. 6, p. 535-539. [CrossRef]

HELLEBRAND, Maja; NAGY, Marion and MÖRSEL, Jörg-Thomas. Determination of DNA traces in rapeseed oil. Zeitschrift für Lebensmitteluntersuchung und - Forschung A, April 1998, vol. 206, no. 4, p. 237-242. [CrossRef]

HOLST-JENSEN, Arne; RØNNING, Sissel B.; LøVSETH, Astrid and BERDAL, Knut G. PCR technology for screening and quantification of genetically modified organisms (GMOs). Analytical and Bioanalytical Chemistry, April 2003, vol. 375, no. 8, p. 985-993. [CrossRef]

JACCAUD, Etienne; HÖHNE, Michaela and MEYER, Rolf. Assessment of screening methods for the identification of genetically modified potatoes in raw materials and finished products. Journal of Agricultural and Food Chemistry, January 2003, vol. 51, no. 3, p. 550-557. [CrossRef]

JAMES, Clive. Executive summary of global status of commercialized Biotech/GM Crops: 2008. The first thirteen years, 1996 to 2008. In: ISAAA Brief, 39. Ithaca, NY, ISAAA, 2008, p. 275.

LIPP, M.; BROADMANN, P.; PIETSCH, K.; PAUWELS, J. and ANKLAM, E. IUPAC collaborative trial study of a method to detect genetically modified soybeans and maize in dried powder. Journal of the AOAC International, 1999, vol. 82, no. 4, p. 923-928.

LIPP, Markus; BLUTH, Anke; EYQUEM, Fabrice; KRUSE, Lothar; SCHIMMEL, Heinz; VAN den EEDE, Guy and ANKLAM, Elke. Validation of a method based on polymerase chain reaction for the detection of genetically modified organisms in various processed foodstuffs. European Food Research and Technology, March 2001, vol. 212, no. 4, p. 497-504. [CrossRef]

Monsanto Biotechnology Regulatory Sciences [online]. A recommended procedure for real-time quantitative TaqMan PCR for Roundup Ready canola Gt73. 2004. [cited date August 8, 2007]. Available from Internet: http://www.monsanto.com/monsanto/content/products/productivity/roundup/canola dna d m.pdf.

NIKOLIC, Zorica; TAŠKI-AJDUKOVIC, Ksenija; TATIC, Mladen and BALEŠEVIC-TUBIC, Svetlana. Monitoring of the roundup ready soybean in the vojvodina province in Serbia. Industrial Crops and Products, March 2009, vol. 29, no. 2-3, p. 638-641. [CrossRef]

PARK, Kee Woong; LEE, Bumkyu; KIM, Chang-Gi; KIM, Do Young; PARK, Ji-Young; KO, Eun$\mathrm{Mi}$; JEONG, Soon-Chun; CHOI, Kyung-Hwa; YOON, Won Kee and KIM, Hwan Mook. Monitoring the occurrence of genetically modified soybean and maize around cultivated fields and at a grain receiving port in Korea. Food Control, April 2010, vol. 21, no. 4, p. 456-461. [CrossRef]

STUDER, Edgar; RHYNER, Claudio; LÜTHY, Jürg and HÜBNER, Philipp. Quantitative competitive PCR for the detection of genetically modified soybean and maize. Zeitschrift für Lebensmitteluntersuchung und -Forschung A, September 1998, vol. 207, no. 3, p. 207213. [CrossRef]

TOZZINI, Alejandro C.; MARTÍNEZ, Carolina M.; LUCCA, M. Florencia; ROVERE, Cecilia V.; DISTÉFANO, Ana J.; DEL VAS, Mariana and HOPP, Esteban H. Semi-quantitative detection of genetically modified grains based on CaMV $35 \mathrm{~S}$ promoter amplification. Electronic Journal of Biotechnology, August 2000, vol. 3, no. 2. [CrossRef]

YANG, Litao; PAN, Aihu; ZHANG, Haibo; GUO, Jinchao; YIN, Changsong and ZHANG, Dabing. Event-Specific qualitative and quantitative polymerase chain reaction analysis for genetically modified canola T45. Journal of Agricultural and Food Chemistry, December 2006, vol. 54, no. 26 , p. $9735-9740$. [CrossRef] 
How to cite this article:

NIKOLIĆ, Z.; VUJAKOVIĆ, M.; JEROMELA, A.M. and JOVIČIĆ, D. Implementation of monitoring for genetically modified rapeseed in Serbia. Electronic Journal of Biotechnology, September 2010, vol. 13, no. 5. http://dx.doi.org/10.2225/vol13-issue5-fulltext-4 